\title{
Sistem kendali posisi motor DC menggunakan state feedback controller dan real-time operating system
}

\author{
Martin* \\ Jurusan Teknik Elektro, Politeknik Negeri Bandung \\ Jl. Gegerkalong Hilir, Ciwaruga, Kec. Parongpong, Kabupaten Bandung Barat, Indonesia \\ "martin@polban.ac.id
}

\begin{abstract}
ABSTRAK
Motor DC merupakan sistem penggerak yang paling banyak digunakan di bidang industri, otomasi, robotika, ataupun lainnya. Penggunaan sistem kendali banyak diterapkan untuk pengaturan pergerakan kecepatan ataupun posisi dari motor DC. Pada penelitian ini, state feedback controller dan penambahan kendali integral dengan estimator digunakan untuk mengendalikan posisi motor DC. Sistem dibuat berbasis real-time operarting system (RTOS) untuk pembacaan sensor, perhitungan matematis kendali, dan pengiriman sinyal pulse width modulation (PWM). Pengendalian dilakukan pada motor DC Quanser yang terhubung dengan Arduino Mega 2560 untuk membaca sensor encoder dan menampilkan data pengujian. Hasil pengujian menunjukkan bahwa state feedback controller dapat mengendalikan posisi motor DC dengan nilai penguat K sebesar 2,66 dan 115,37, nilai penguat $\mathrm{N}$ bar sebesar 0,49 dan nilai estimator sebesar 7,75 dan 0,26. Penggunaan RTOS sebagai inti pemrograman dapat menyelesaikan permasalahan dalam pengerjaan task-task seperti pembacaan sensor, perhitungan parameter kendali, dan pengiriman sinyal kendali tanpa terjadi error selama pengujian sistem. Hasil analisa menunjukan keluaran sistem kendali posisi memiliki nilai overshoot sebesar $2,63 \%$ pada pengujian pertama dan $2,66 \%$ pada pengujian kedua.
\end{abstract}

Kata kunci: state feedback controller, real-time operating system, motor DC Quanser

\section{ABSTRACT}

DC motors are the most widely used drive systems in industry, automation, robotics, or others. The use of a control system is widely applied to adjust the speed or position movement of the DC motor. In this study, the state feedback controller and the addition of an integral control with an estimator are used to control the position of the DC motor. The system is made based on a real-time operating system (RTOS) for sensor readings, control mathematical calculations, and pulse width modulation (PWM) signal transmission. Control is carried out on a Quanser DC motor connected to the Arduino Mega 2560 to read the encoder sensor and display the test data. The test results show that the state feedback controller can control the position of the DC motor with amplifier $K$ values of 2.66 and 115.37, $N$ _bar amplifier values of 0.49 and estimator values of 7.75 and 0.26. The use of RTOS as the core of programming can solve problems in carrying out tasks such as reading sensors, calculating control parameters, and sending control signals without errors during system testing. The results of the analysis show that the position control system output has an overshoot value of $2.63 \%$ in the first test and $2.66 \%$ in the second test.

Keywords: state feedback controller, real-time operating system, Quanser DC motor

\section{PENDAHULUAN}

Motor DC merupakan salah satu komponen penting yang banyak digunakan dalam industri, otomotif, ataupun kehidupan sehari-hari. Penggunaan komponen tersebut seperti pada mobil remote control, penggerak belt conveyor, ataupun dapat digunakan sebagai generator. Motor DC merupakan salah satu penggerak elektrik yang sangat sering digunakan dan juga dikembangkan karena motor DC mudah untuk dikendalikan menggunakan kendali linier [1]. Salah satu pengembangan yang paling banyak dilakukan yaitu dengan mengatur atau mengendalikan dari posisi pergerakan motor DC. Posisi dari pergerakan motor DC dapat diketahui dan dikendalikan dengan meletakan sensor untuk mendeteksi perubahan yang telah terjadi. Sensor encoder merupakan salah satu komponen untuk membaca pergerakan kecepatan ataupun posisi putaran motor DC. Sensor tersebut menghasilkan 
keluaran berupa tegangan DC yang akan dijadikan umpan balik dari alat yang akan dikendalikan. Penerapan kendali posisi pada motor DC merupakan sebuah tantangan tersendiri dengan banyaknya jenis kendali yang telah ditemukan, seperti kendali proporsional integral derivatif (PID), logika fuzzy, pole placement, linear quadratic regulator (LQR), dan linear quadratic gaussian (LQG) [2], [3].

Penelitian tentang pengendalian motor DC berserta penerapannya telah banyak dilakukan. Peneliti [4] melakukan penelitian tentang pemodelan dan kendali posisi dari sebuah motor DC. Peneliti tersebut melakukan perbandingan antara kendali PID dan LQR dalam mengendalikan posisi motor DC yang telah dimodelkan. Pada penelitian [5] menampilkan pengendalian kecepatan motor brushless DC (BLDC) menggunakan hall-effect position sensor sebagai umpan balik untuk mengetahui kecepatan motor BLDC. Hasil dari penelitian tersebut menampilkan bahwa sensor posisi dapat digunakan sebagai pendeteksi kecepatan motor BLDC. Logika fuzzy juga digunakan pada penelitian [6]-[8] untuk mengendalikan posisi sebuah motor DC, walaupun terdapat perbedaan logika fuzzy yang digunakan pada ketiga judul penelitian tersebut. Penelitian [6] menggunakan fast fuzzy controller untuk mengendalikan posisi motor DC yang diimplementasikan pada field-programmable gate array (FPGA). Kemudian penelitian [7] menggunakan adaptive fuzzy controller untuk mengendalikan motor DC dengan melakukan pengoptimalan dalam pengendalian berbagai jenis beban pada sistem. Selanjutnya peneliti [8] melakukan penelitian untuk mengendalikan posisi motor DC menggunakan logika fuzzy digabungkan dengan kendali proporsional integral (PI). Logika fuzzy digunakan untuk menentukan parameter PI terbaik yang akan diimplementasikan pada pengedalian posisi motor DC. Adapun penerapan pada kendali posisi motor DC salah satunya untuk solar tracking system. Pengendali sliding mode digunakan untuk mengendalikan posisi motor DC sehingga dapat mengikuti arah cahaya matahari agar dapat digunakan maksimal pada panel surya [9]. Pengendali LQG yang digabungkan dengan filter Kalman juga dapat digunakan sebagai kendali posisi motor DC. Pengoptimalan nilai penguatan umpan balik dilakukan oleh filter Kalman seperti pada penelitian [10]. Pengendali lainnya yang dapat digunakan yaitu pole placement atau yang dapat disebut state feedback controller. Penguatan diberikan pada umpan balik sistem dan masukan sistem dimana penguatan tersebut didapatkan berdasarkan perhitungan matematis yang didapatkan setelah mengetahui model dari sistem yang akan dikendalikan. Terakhir, penelitian [11] dan [12] merancang kendali state feedback dengan menerapkan pengendalian pada jenis motor DC yang berbeda.

Dalam penelitian ini akan dilakukan pengendalian posisi motor DC menggunakan state feedcback controller dan diimplementasikan pada mikrokontroler yang telah diberikan real time operating system (RTOS). Motor DC dikopling dengan high resolution optical encoder dimana telah diketahui modelnya. Penelitian-penelitian yang dijadikan sebagai referensi hanya menggunakan metode loop standar ataupun super-loop dalam menjalankan task program. Pada penelitian ini, penggunaan RTOS bertujuan untuk menjalankan perintah-perintah dalam melaksanakan task baik dalam pembacaan sensor, pengendalian motor, ataupun menampilkan grafik sehingga dapat memaksimalkan pelaksanaan task. Pelaksanaan task dilaksanakan lebih cepat dengan delay yang sangat rendah. Penggunakan RTOS pada mikrokontroler akan sangat berbeda apabila dibandingkan hanya dengan menggunakan loop ataupun super-loop program.

\section{METODE PENELITIAN}

\subsection{State Feedback Controller}

Pole placement merupakan dasar dalam metode state feedback controller yaitu dengan mengasumsikan bahwa semua variabel dapat terukur dan bisa dijadikan umpan balik sistem yang digunakan. Namun, pada pengendalian ini semua sistem harus dapat teramati dan terkendali. Metode ini digunakan dengan menentukan nilai kutub-kutub berdasarkan respon sistem bentuk transien ataupun frekuensi, seperti kecepatan, damping rasio, atau bandwidth [2].

Untuk mendapatkan nilai kutub yang digunakan, diasumsikan terdapat satu masukan dan satu keluaran pada sistem. Kemudian sistem terkendali dimana semua variabel terhubung ke bagian masukan. Setelah sistem dalam keadaan close loop, maka dapat dicari nilai kutub yang akan digunakan. 
Asumsikan sistem dinamik linier sebagai berikut

$$
\begin{aligned}
& \dot{x}=A x+B u \\
& y=C x+D u
\end{aligned}
$$

dengan

$$
u=-K x
$$

dimana $x$ adalah vektor state ( $n$-vector), $y$ adalah sinyal keluaran (skalar), $u$ adalah sinyal kontrol (skalar), $A, B, C, D$ berturut-turut adalah matriks konstan berdimensi $\mathrm{n} \times \mathrm{n}$, dan $K$ adalah matriks konstan berdimensi $1 \mathrm{x} \mathrm{n}$.

Setalah diketahui persamaan (1) sampai (3) ditentukan bahwa masukan sistem adalah state yang kontinyu yang didapatkan dari sinyal umpan balik. Nilai $K$ merupakan matriks penguatan pada sistem yang berdimensi 1 x n. Bila persamaan (3) disubstitusikan ke persamaan ke (1), maka akan didapatkan persamaan baru seperti dibawah ini.

$$
\dot{x}=(A-B K) x
$$

Sesuai dengan persamaan (4), maka kestabilan dan transien respon ditentukan oleh nilai eigen dari matriks $A-B K$. Nilai $K$ didapatkan dari karakteristik sistem yang diinginkan sehingga didapatkan matriks yang stabil dan nilai eigen dari $A-B K$ merupakan kutub regulator dari sistem. Penempatan kutub disesuaikan dengan variabel yang akan dijadikan umpan balik. Diagram blok dari persamaan (4) akan didapatkan seperti Gambar 1.

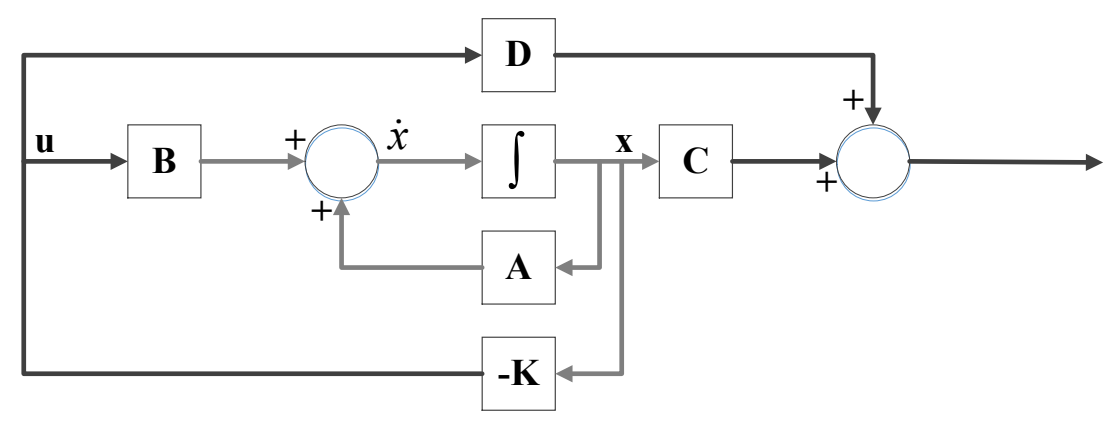

Gambar 1. Diagram blok pole placement

Persamaan (4) yang telah dijelaskan merupakan state feedback controller dengan status tidak penuh. State feedback controller berstatus penuh dapat dibuat dengan menambahkan kendali integral pada state feedback controller dengan status tidak penuh. Diagram blok dari state feedback controller pada sebuah sistem close loop dengan masukan acuan (r) dapat dilihat pada Gambar 2.

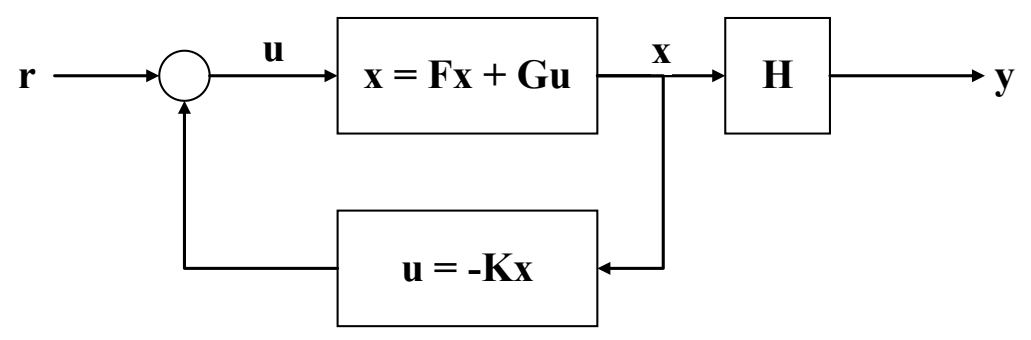

Gambar 2. Diagram blok dengan masukan acuan

Sistem akan mempunyai kesalahan dalam keadaan setimbang tak nol terhadap masukan langkah. Untuk mengoreksinya, pada keadaan setimbang dihitung nilai status dan masukan kendali yang menghasilkan kesalahan keluaran nol, kemudian menekannya untuk bertahan pada nilai ini. Bila nilai akhir dari status ini dan masukan kendali adalah $x_{s s}$ dan $u_{s s}$, maka formula kendali yang baru sebagai berikut [3]. 


$$
u=u_{s S}-K\left(x-x_{s s}\right)
$$

Bila nilai $x$ sama dengan nilai $x_{s s}$, maka nilai $u$ sama dengan nilai $u_{s s}$. Nilai kesalahan setimbang harus bernilai nol terhadap sembarang masukan, agar nilai akhir atau keluaran akan sama dengan nilai masukan acuan dari sistem. Persamaan (1) dan (2) jika matrik A, B, C dan D diubah menjadi F, G, H dan J dalam keadaan setimbang akan berubah menjadi persamaan dibawah ini.

$$
\begin{aligned}
& 0=F x_{s s}+G u_{s s} \\
& y=H x_{s s}+J u_{s s}
\end{aligned}
$$

Dengan demikian, nilai keluaran sama dengan nilai masukan acuan $\left(\mathrm{y}_{\mathrm{ss}}=\mathrm{r}_{\mathrm{ss}}\right)$ dengan nilai $\mathrm{r}_{\mathrm{ss}}$ sembarang dan dinyatakan dalam

$$
x_{s s}=N_{x} r_{s s}, u_{s s}=N_{u} r_{s s}
$$

Persamaan kendali dengan menggabungkan persamaan (7) sampai dengan (8) yang telah didapatkan state space yaitu seperti berikut.

$$
\left[\begin{array}{ll}
F & G \\
H & J
\end{array}\right]\left[\begin{array}{l}
N_{x} \\
N_{u}
\end{array}\right]=\left[\begin{array}{l}
0 \\
1
\end{array}\right]
$$

Untuk memperoleh kesalahan setimbang sistem nol, maka masukan acuan harus memenuhi nilai seperti persamaan (10), sedangkan nilai $N_{u}$ dan $N_{x}$ dapat dijadikan komposit tunggal sehingga didapatkan persamaan (11) dibawah ini.

$$
\begin{gathered}
u=-K x+\left(N_{u}+K N_{x}\right) r \\
u=-K x+\bar{N} r
\end{gathered}
$$

Dengan demikian, akan dihasilkan diagram blok kendali lingkar tertutup seperti pada Gambar 3 berikut

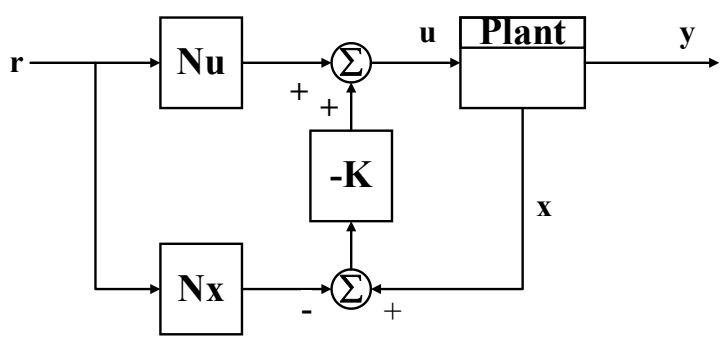

(a)

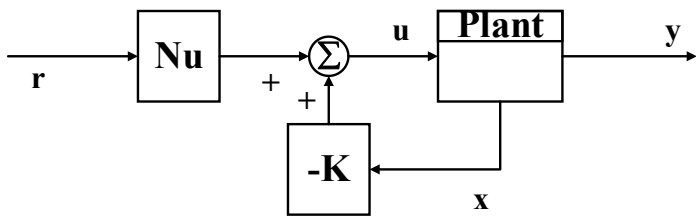

(b)

Gambar 3. Diagram blok full state feedback controller: (a) persamaan (10), (b) persamaan (11)

\subsection{Real Time Operating System}

Sebagian besar pengendalian sistem dinamik akan memiliki masalah pada waktu pengerjaan program. Dalam pengendalian, berbagai perintah harus diterima pada waktu yang tepat untuk memastikan pengoperasian berjalan dengan lancar dan memenuhi real-time [13]. Real-time operating system (RTOS) adalah suatu sistem operasi multitasking yang diperuntukan untuk aplikasi real-time. RTOS dapat menjadikan sistem dapat bekerja secara real-time, akan tetapi hasil akhir yang diperoleh tidak dapat dipastikan akan bekerja secara real-time. Hal ini dipengaruhi oleh beberapa faktor dan pengembangan yang dilakukan oleh pengembang dengan baik. Karakter dasar dari RTOS yaitu sistem yang memiliki beberapa konsekuensi yang dapat mempengaruhi kinerja sistem apabila batas waktu dari pelaksanaan task tidak terpenuhi. Berdasarkan karakteristik itu sendiri, RTOS terbagi menjadi dua bagian yaitu soft dan hard RTOS. Soft RTOS merupakan sistem yang dalam menjalani sistem memiliki tingkat persentase penyelesaian waktu secara real-time sebesar kurang dari 100\%, sedangkan hard RTOS merupakan sistem yang dapat menyelesaikan task dalam waktu yang telah ditentukan 
dengan tingkat keberhasilan $100 \%$. Penjelasan RTOS akan dibagi menjadi tiga poin utama, antara lain task, kernel, dan mutual exclusion atau pengerjaan diwaktu yang sama.

Task merupakan sebuah objek/program yang dieksekusi dan dijalankan layaknya mempunyai CPU tersendiri. Pembagian pekerjaan dalam aplikasi menjadi beberapa task merupakan salah satu proses perancangan dari sebuah RTOS. Setiap task merupakan lingkaran yang akan terus berulang selama proses menjalankan aplikasi. Selama proses tersebut, task akan mengalami tiga buah keadaan seperti yang ditunjukan oleh Gambar 4.

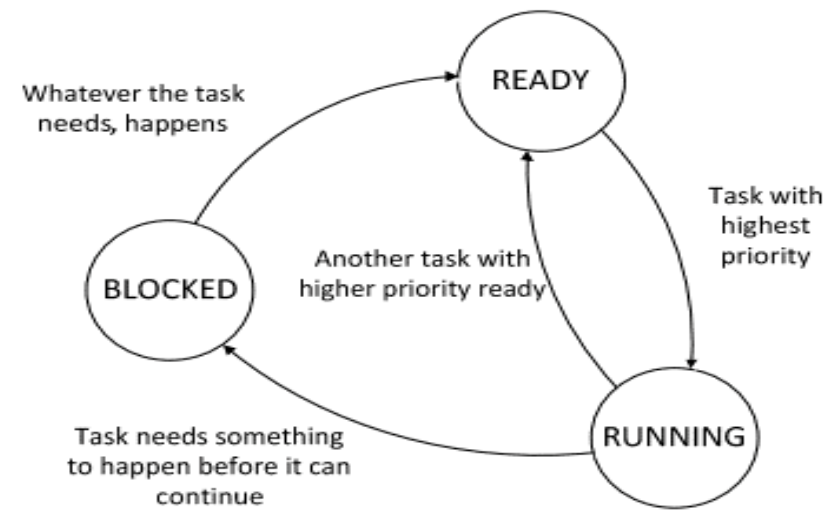

Gambar 4. Siklus state pada sebuah RTOS [13]

Kernel merupakan salah satu bagian dari sistem multitasking yang mempunyai fungsi sebagai manajemen dari seluruh task, mengatur komunikasi tiap task, dan yang terpenting adalah mengatur pewaktuan untuk central processing unit (CPU) sehingga tidak terjadi crash pada CPU. Untuk kernel sendiri terdiri dari dua jenis yaitu, non-preemptive dan preemptive. Dalam sistem yang digunakan akan menggunakan RTOS yang bersifat preemptive.

Preemptive kernel banyak digunakan untuk membuat aplikasi dengan RTOS. Hal ini karena preemptive kernel mempunyai respon yang lebih bagus daripada non-preemptive kernel. Jadi dapat disimpulkan bahwa preemptive kernel selalu mendahulukan task dengan prioritas tertinggi yang siap untuk dieksekusi. Dengan preemptive kernel, respon sistem bisa mencapai optimal dan waktu untuk menjalankan task dengan prioritas tertinggi bisa ditentukan, berbeda dengan non-preemptive kernel yang tidak bisa ditentukan. Gambar 5 menampilkan prinsip kerja preemptive kernel.

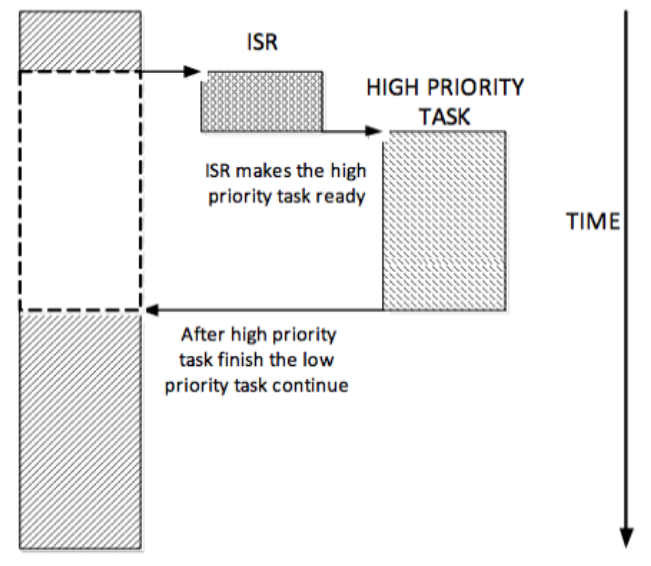

Gambar 5. Prinsip kerja preemptive kernel [13]

Mutual exclusion merupakan kondisi setiap sumber daya diberikan tepat pada satu waktu. Ada beberapa metode untuk mendukung mutual exclusion, antara lain adalah semaphore dan message queue. Message queue digunakan untuk mengirim satu atau lebih pesan kepada message queue digunakan untuk mencegah terjadinya error karena shared data. 


\subsection{Perancangan Perangkat Keras}

Perancangan perangkat keras menggunakan dilakukan menggunakan modul motor DC Quanser yang dihubungkan ke Arduino Mega 2560 untuk membaca nilai sensor encoder sebagai umpan balik sistem. Diagram blok perangkat keras dan perangkat keras yang digunakan dapat dilihat pada Gambar 6 dan Gambar 7.

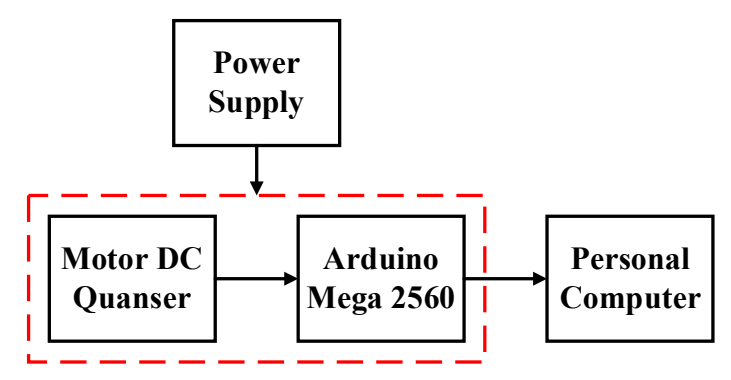

Gambar 6. Diagram blok perangkat keras

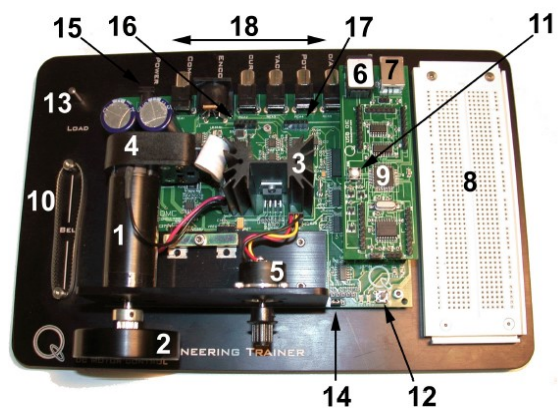

Gambar 7. Motor DC Quanser

Modul motor DC Quanser seperti pada Gambar 7 memiliki beberapa komponen yang akan digunakan dan ada juga yang tidak akan digunakan dengan detail pada Tabel 1 berikut.

Tabel 1. Deskripsi komponen motor DC Quanser pada Gambar 7

\begin{tabular}{|c|l|}
\hline No. & \multicolumn{1}{|c|}{ Deskripsi } \\
\hline 1 & Maxon DC motor \\
\hline 2 & Removable inertial load \\
\hline 3 & Linear power amplifier \\
\hline 4 & High resolution optical encoder \\
\hline 5 & Ball bearing servo potentiometer \\
\hline 6 & $\begin{array}{l}\text { RJ11 port on QIC: for downloading firmware using a compatible } \\
\text { programming device }\end{array}$ \\
\hline 7 & USB port on QIC: for online tuning and plotting using LABview \\
\hline 8 & Breadboard option: to implement controllers with your own circuits \\
\hline 9 & Embedded/portable option \\
\hline 10 & Removable belt: to drive potentiometer \\
\hline 11 & PIC reset switch \\
\hline 12 & User switch \\
\hline 13 & Inertial load storage pin \\
\hline 14 & Jumper J6: switch between DAQ and QIC \\
\hline 15 & 6-mm power jack \\
\hline 16 & Power supply header: J4 \\
\hline 17 & Analog signal header: J11 \\
\hline 18 & $\begin{array}{l}\text { i. } \text { PC interface option } \\
\text { ii. Analog controller option }\end{array}$ \\
\hline
\end{tabular}

Block circuit motor DC Quanser yang akan digunakan dapat dilihat pada Gambar 8 . Adapun model fungsi transfer pada motor DC Quanser telah diketahui dari datasheet dengan persamaan sebagai berikut.

$$
T f_{m}=\frac{19,3}{0,07 s^{2}+s}
$$




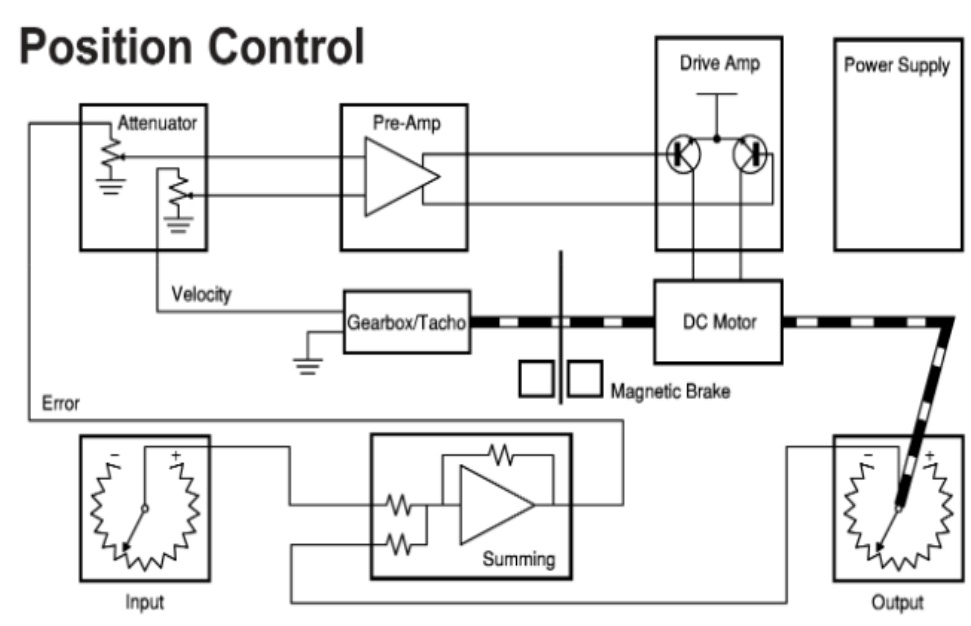

Gambar 8. Block circuit motor DC

\subsection{Perancangan Perangkat Lunak}

Perancangan perangkat lunak pada implementasi ini sesuai dengan tujuan yaitu bagaimana menghubungkan RTOS dengan kendali state feedback controller dalam sistem embedded untuk mengontrol posisi motor. Perangkat lunak MATLAB digunakan untuk mengetahui nilai penguatan $K$, estimator $L$, dan $\bar{N}$. Flowchart perangkat lunak kendali state feedback controller, serta nilai $K, L$, dan $\bar{N}$ dapat dilihat pada Gambar 9.

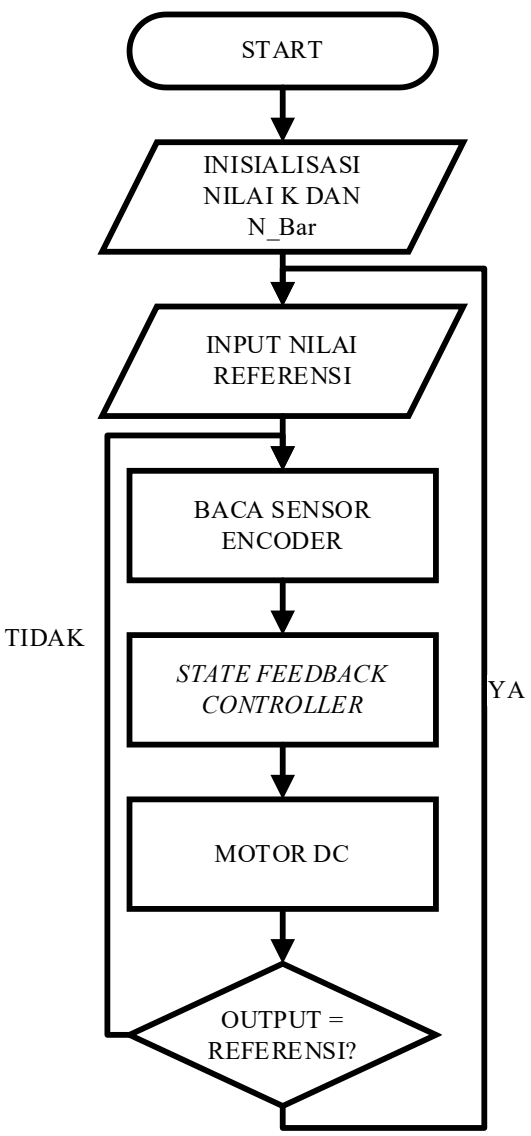

(a)

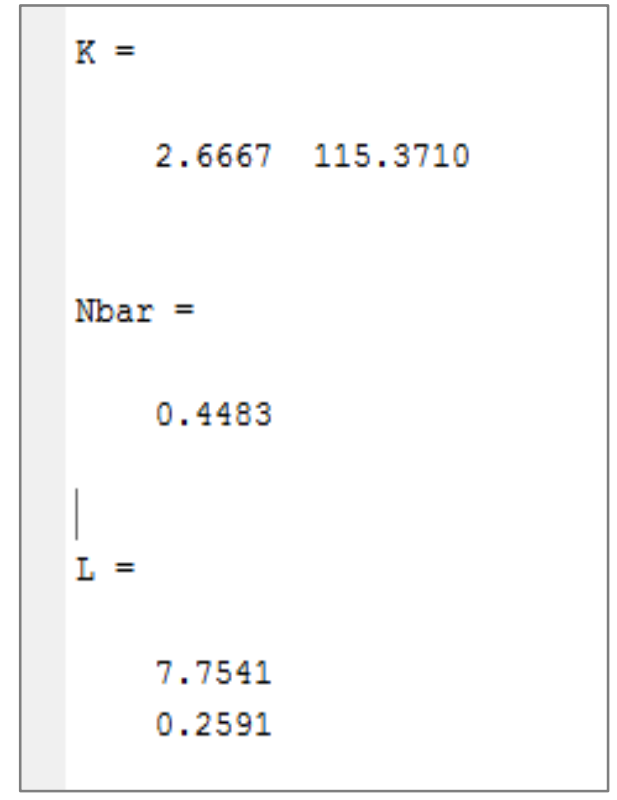

(b)

Gambar 9. Perangkat lunak: (a) flowchart kendali posisi motor DC, (b) nilai $K, L, \operatorname{dan} \bar{N}$ 


\section{HASIL DAN PEMBAHASAN}

Pengujian dilakukan secara eksperimental pada sistem kendali posisi motor DC menggunakan state feedback controller berbasis RTOS. Data yang akan ditampilkan yaitu sinyal kendali, sinyal estimator, dan grafik keluaran pengujian sistem secara keseluruhan. Spesifikasi sistem yang diharapkan pada kendali posisi motor DC dapat dilihat pada Tabel 2. Gambar 10, Gambar 11, dan Gambar 12 merupakan hasil pengujian yang telah dilakukan.

Tabel 2. Spesifikasi pengendalian yang diharapkan

\begin{tabular}{|l|l|}
\hline \multicolumn{1}{|c|}{ Spesifikasi } & \multicolumn{1}{c|}{ Nilai } \\
\hline Maksimum \% overshoot & $\leq 3 \%$ \\
\hline Time sampling $\left(\mathrm{T}_{\mathrm{s}}\right)$ & 0,5 detik \\
\hline Error steady state $\left(\mathrm{E}_{\mathrm{ss}}\right)$ & $\leq 10$ \\
\hline Desired pole $\left(\mathrm{K}_{1} / \mathrm{K}_{2}\right)$ & $0 \leq \mathrm{K}_{1} / \mathrm{K}_{2} \leq 150$ \\
\hline
\end{tabular}

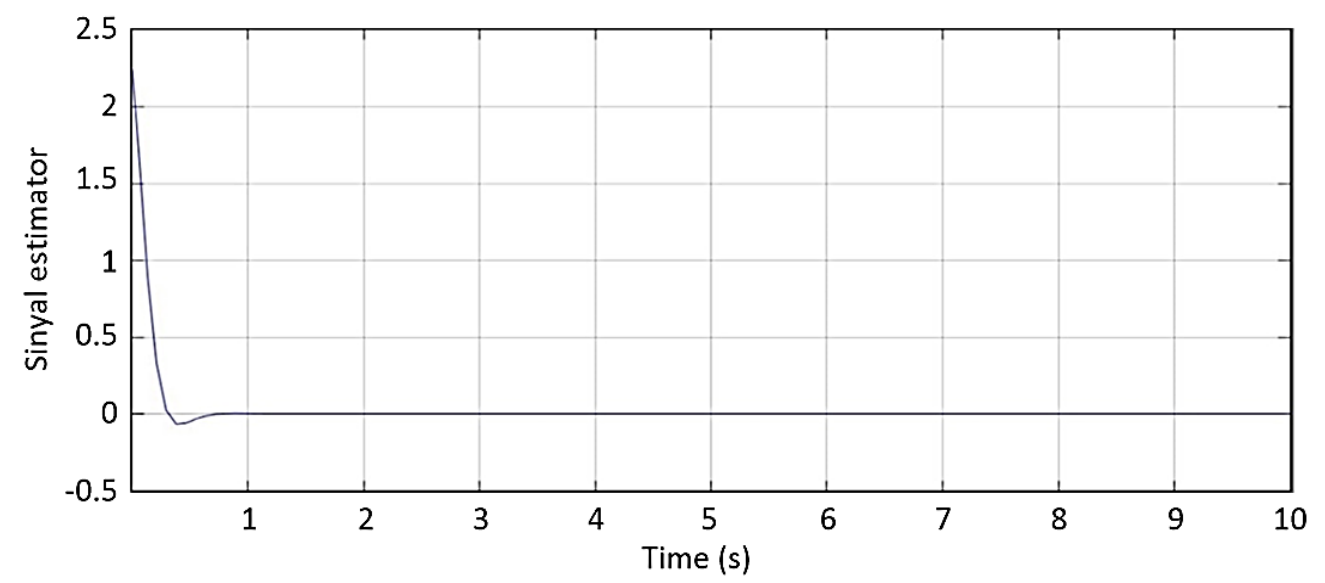

(a)

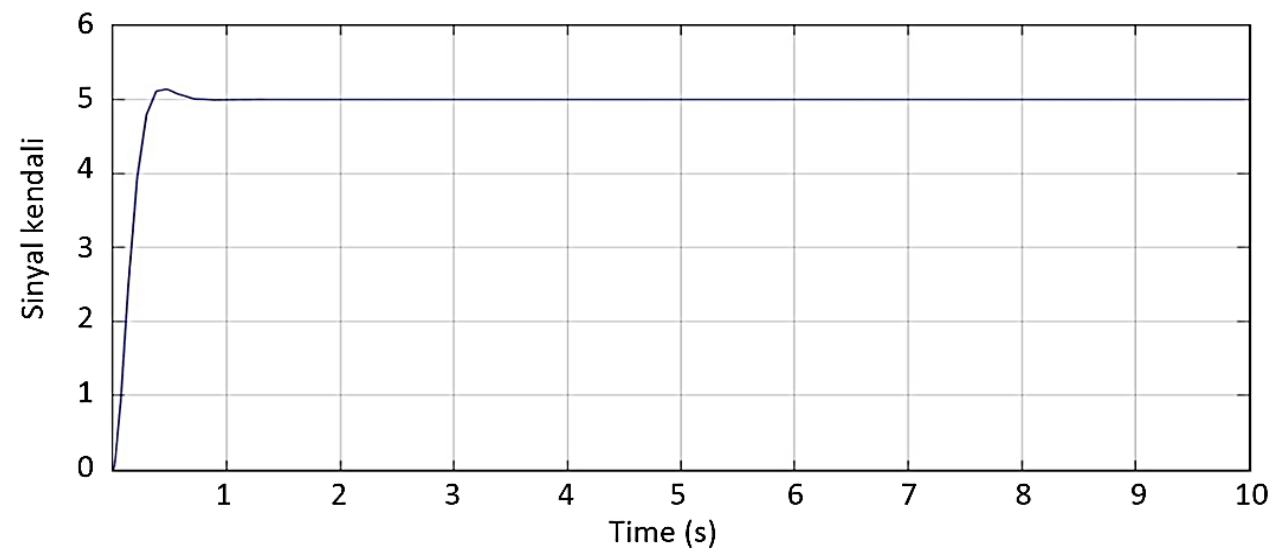

(b)

Gambar 10. Hasil pengujian sistem: (a) respon sinyal estimator, (b) respon sinyal kendali

Gambar 10 merupakan respon keluaran hasil simulasi yang dilakukan pada perangkat lunak MATLAB. Simulasi dengan parameter nilai penguat $K, L$, dan $\bar{N}$ dilakukan untuk menguji perkiraan respon keluaran sistem kendali posisi motor DC. Parameter state feedback controller diperoleh melalui perhitungan dari persamaan (1) hingga (11), serta menggunakan persamaan (12) sebagai fungsi transfer motor DC. Hasil perhitungan tersebut menghasilkan nilai penguat $K$ sebesar 2,66 dan 115,37, nilai penguat $\bar{N}$ sebesar 0,45 dan nilai penguat $L$ sebesar 7,75 dan 0,26. 


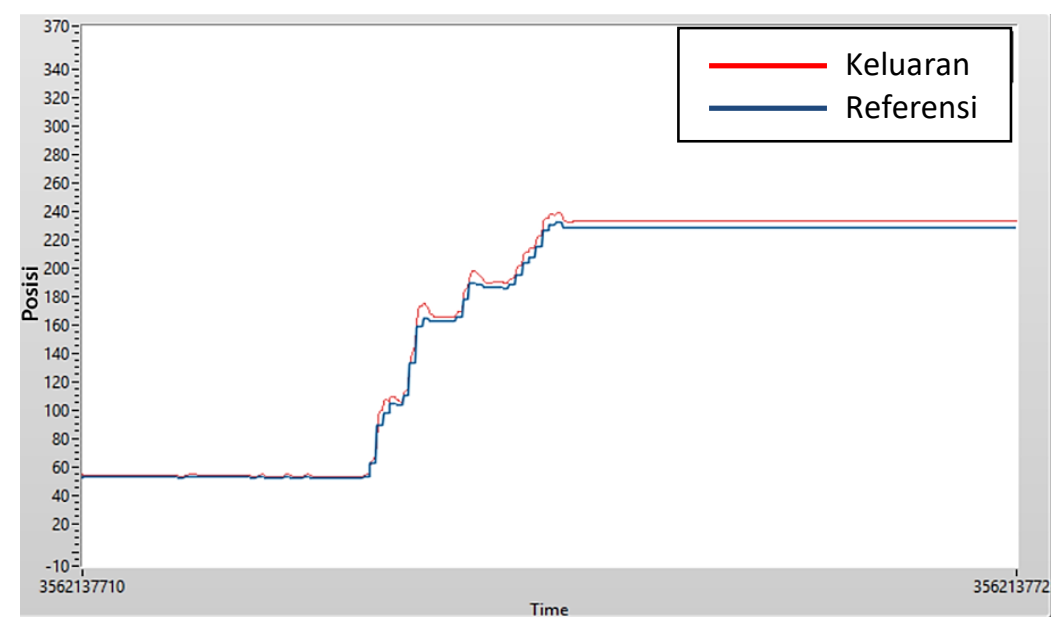

Gambar 11. Respon keluaran pengujian kesatu

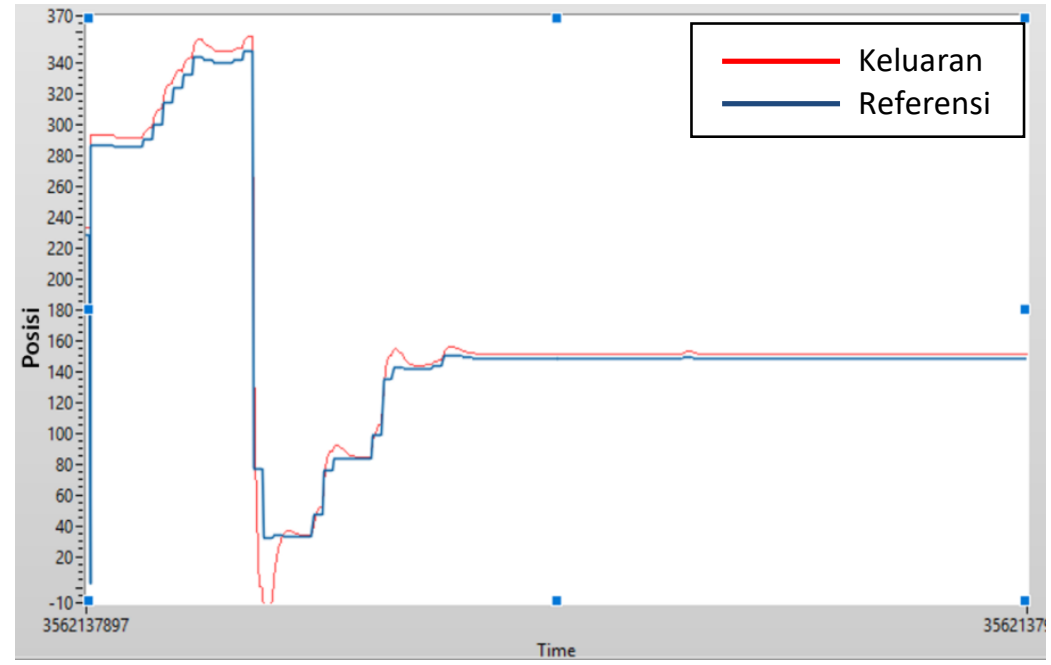

Gambar 12. Respon keluaran pengujian kedua

Hasil sinyal keluaran respon kendali posisi motor ditunjukkan pada Gambar 11 dan Gambar 12. Hasil pengujian menunjukan penggunaan RTOS sebagai inti pemrograman dapat berjalan dengan baik tanpa terdapat error atau keterlambatan baik dalam pengukuran sensor ataupun pengiriman sinyal kendali. Hal ini berdampak pada keluaran respon yang tidak sesuai rancangan spesifikasi sistem, dimana sistem memiliki nilai time sampling $\left(\mathrm{T}_{\mathrm{s}}\right)$ sebesar 0,2 detik. Gambar 11 menunjukan respon keluaran sistem memiliki nilai overshoot sebesar 234 dan nilai steady state sebesar 230 dengan nilai setpoint sebesar 228, maka nilai \% overshoot respon keluaran sebesar 2,63\% dan nilai $\mathrm{E}_{\mathrm{ss}}$ sebesar 2 . Gambar 13 memiliki nilai overshoot sebesar 154 dan nilai steady state sebesar 152 dengan nilai setpoint 150 , maka nilai \% overshoot sebesar $2,66 \%$ dan nilai $\mathrm{E}_{\mathrm{ss}}$ sebesar 2 . Keluaran sistem kendali posisi motor DC ini sesuai dengan rancangan spesifikasi sistem yang ditampilkan pada Tabel 2.

\section{KESIMPULAN}

Berdasarkan hasil uji coba pada sistem didapatkan bahwa pengendalian posisi motor DC menggunakan state feedback controller dan RTOS dapat berjalan sesuai tujuan dan spesifikasi sistem yang diinginkan. RTOS mampu melaksanakan task yang diberikan dengan baik, sehingga selama pengendalian posisi motor DC tidak terjadi error dalam pengukuran nilai sensor dan pengiriman sinyal kendali kepada motor DC. Hasil analisa dari data pengujian didapatkan nilai spesifikasi pengendalian yang telah ditentukan dapat dicapai. Penelitian selanjutnya dapat dilakukan pengembangan pada metode pengendalian yang lebih baik, khususnya untuk mengatasi adanya gangguan dan derau pengukuran. 


\section{UCAPAN TERIMA KASIH}

Terima kasih disampaikan kepada Institut Teknologi Bandung, Sekolah Teknik Elektro dan Informatika, Opsi Kendali dan Sistem Cerdas, atas fasilitas yang penyediaan fasilitas penelitian berupa motor DC Quanser.

\section{REFERENSI}

[1] S. K. Das, N. Mondol, and N. A. Sultana, "DESIGN AND IMPLEMENT OF A STATE FEEDBACK POSITION OUTPUT CONTROLLER FOR A MAXON S-DC MOTOR WITH dSPACE," in International Conference on Mechanical Engineering 2011, 2011, vol. 2011, pp. 18-20.

[2] K. Ogata, Modern Control Engineering, Fifth. New Jersey: Prentice Hall, 2010.

[3] G. F. Franklin, J. D. Powell, and A. Emami-Naeini, Feedback Control of Dynamic Systems, Eight. New York: Pearson, 2018.

[4] J. Chotai and K. Narwekar, "Modelling and Position Control of a DC Motor," in IEEE Proceedings: Electric Power Applications, 2017, pp. 1-8.

[5] P. Mukherjee and M. Sengupta, "Closed loop speed control of a laboratory fabricated brush-less DC motor drive prototype using position sensor," in 2017 National Power Electronics Conference, NPEC 2017, 2018, vol. 2018, no. 1, pp. 166-171.

[6] H. P. Wang, "Design of fast fuzzy controller and its application on position control of DC motor," in 2011 International Conference on Consumer Electronics, Communications and Networks, CECNet 2011 Proceedings, 2011, pp. 4902-4905.

[7] K. Sharma and D. K. Palwalia, "A modified PID control with adaptive fuzzy controller applied to DC motor, " in 2017 International Conference on Information, Communication, Instrumentation and Control (ICICIC), 2017, pp. 1-6.

[8] R. Manikandan and R. Arulmozhiyal, "Position control of DC servo drive using fuzzy logic controller," 2014.

[9] K. Boudaraia, H. Mahmoudi, M. Abbou, and M. Hilal, "DC motor position control of a solar tracking system using second order sliding mode," in International Conference on Multimedia Computing and Systems -Proceedings, 2017, vol. 0, no. 3, pp. 594-598.

[10] M. A. Aravind, N. Saikumar, and N. S. Dinesh, "Optimal position control of a DC motor using LQG with EKF," 2017 Int. Conf. Mech. Syst. Control Eng. ICMSC 2017, no. 2, pp. 149-154, 2017.

[11] M. Mohamed and A. Mahmoud, "Design of State Feedback Gain Matrix for DC Motor Control Based on Damping Ratio and Natural Frequency,” Int. J. Eng. Comput. Sci., vol. 2, no. 7, pp. 2186-2188, 2013.

[12] S. A. Kamilu, M. D. A. Hakeem, and L. Olatomiwa, "Design and Comparative Assessment of State Feedback Controllers for Position Control of 8692 DC Servomotor," Int. J. Intell. Syst. Appl., vol. 7, no. 9, pp. 28-33, 2015.

[13] F. Rammig, "Basic concepts of real time operating systems," in Hardware-dependent Software: Principles and Practice, Munich, Germany: Springer, 2009, pp. 15-45. 